UDC: $005.6 / .7 / .9$

http://doi.org/10.21272/mmi.2019.3-14

JEL Classification: D 23, L29, M14

\title{
Anna Pietruszka-Ortyl,
}

Ph.D., Assistant Professor, Cracow University of Economics, Poland

\section{THE IMPACT OF ORGANIZATIONAL CULTURE FOR COMPANY'S INNOVATION STRATEGY}

Abstract. The resource-based view recognizes present organizational culture as a key component to its success or failure. It has a direct impact on the innovation strategy of organizations and therefore should be treated as a determinant of the organisation's future. Presently companies should naturally strive to make efforts aiming at the creation of such organizational cultures which would affirm knowledge - cultures characteristic for organisations based on knowledge, that foster engagement of employees, building trust and sharing knowledge. They are most often convergent and mutually complementary and described as: lean culture, learning organization culture, information culture, group-development culture. One type of the organizational cultures indicated as optimal for operating in knowledge-based economy is the quality culture. Concentration on quality is currently a sine qua non-condition for the survival and development of modern organization and at the same time, one of the main tasks of managers. Because of the fact that that instruments are in place but still there is a lack of quality culture in the practical aspects and also common point of view that there is a gap to be filled in the development of appropriate culture for quality, the study provides an initial comparative verification of which stage of evolution towards quality culture is represented by companies from different sectors in Poland. The paper has theoretical-empirical ladder. Its aims are to review existing literature dedicated to organisational quality culture essence, elements, determinants and dimensions. Investigation of the topic in the paper is carried out in the following logical sequence: TQM implementation $\rightarrow$ Organizational culture $\rightarrow$ Quality culture $\rightarrow$ Organizational Quality Culture. The purpose of this paper is to describe components of organisational quality cultures in polish enterprises from different sectors. The methodological tool of the research methods was survey questionnaire, included 20 closed-ended questions - most of them multiple choice. It was decided to research, in the context of quality culture, all enterprises: those operating in production, in services and also mixed enterprises. Based on exploration of empirical data, the condition of quality culture in companies operating in Poland is diagnosed. Paper proves that verified organisations are on their way in the direction to the phase of permanent organisational quality culture creation. The results of the research can be useful for developing the complex model of organizational quality culture constitution. They can also provide managers with valuable suggestions on building stable organizational quality culture.

Keywords: empirical study, enterprises, organizational culture, organizational quality culture, quality, quality culture, quality management.

Introduction. In the case of modern organisations, functioning essentially in a knowledge-based economy, culture and quality are the two main, interpenetrating aspects determining their survival and development.

Organisational culture became a subject of interest for both theoreticians and practitioners of management as early as in the 1980s. A leading position, as one of the main soft strengths of a company, was achieved as a result of the emergence of the resource-based approach and orientation towards intangible assets, among other things. At the turn of the 21st century, it was concluded that at the present time, organisational culture affected the survival and development of the enterprise, and should be treated as a factor of the organisation's future success.

For instance, this position is supported by Ambekar et. al. (2019: 146), who postulate that organisational culture determines all aspects of the functioning of a modern organisation. The statement that organizational culture is widely viewed as one of the most important factors contributing to organizational success, is also promoted by Kane et al. (2018: 392). Also Barney's well-known view recognizes organizational culture as a key component to provide a competitive advantage to organizations that have a direct impact on the innovation strategy of organizations (Pietersen, 2017: 263).

Cite as: Pietruszka-Ortyl, A. (2019). The Impact of Organizational Culture for Company's Innovation Strategy. Marketing and Management of Innovations, 3, 178-192. http://doi.org/10.21272/mmi.2019.3-14 
Such a view on it results from specific attributes of the organizational culture. Firstly, it is indicated that it is one of the main intangible resources with an essential impact on the level of the intellectual capital of a company, and hence presently determining its value (Al Saifi, 2015: 164). Secondly, it is listed as a factor conditioning the effectiveness information governance (Daneshmandnia, 2019: 18) or knowledge management in an organization (Corfield, Paton, 2016: 88), including the willingness to share knowledge (Tong, 2014, pp. 19-28). Finally, it is seen as an element decisive for a company's innovativeness (Laforet, 2016: 379), as well as satisfaction from work (Tong, 2014: 19-28) and the quality of this work (Wyrostek, 2012: 43-49).

Its beneficial effects on the organisation's operation are also confirmed by the results of empirical research conducted in specific sectors and industries - in the coal industry (Ambekar et al., 2019: 146), shipping industry (Karakasnaki et al., 2019), hospitality industry (Manning, 2018: 284), banking system (Famiyeh et al., 2017: 1546), service industries (Khan and Naeem, 2018: 1568) and production industries (Patyal and Koilakuntla, 2018: 1406).

It is therefore assumed that organisational culture is now widely seen as one of the most important and valuable factors in organisational success across a wide variety of business sectors (Taylor and Rostron, 2018: 313). Furthermore, according to the functionalistic paradigm, it is perceived as the object of management (Sulkowski, 2013a: 20).

A contemporary definition of organizational culture is that it is shared set of values, norms, assumptions, and beliefs that exist among organizational members, which influence employee attitudes, thoughts, feelings, decisions, and behaviours. Therefore understanding organizational culture is about symbol, ideational systems, myth, and ritual or about the art of reading and understanding organizational life (Pietersen, 2017: 263). It consists of a cluster of common norms and values, which are formed over a long time and affect the way an organisation works (Ingelsson et al., 2018: 1751). Because of that a new organisational culture is nowadays developed to support and improve the organisation's core activities (Tenji and Foley, 2019: 401).

The philosophy of quality management has also evolved from a mere inspection activity to an important managerial function in an organization, over the last century (Gouda et al., 2019: 55). Managing quality is nowadays recognised as one of the most significant core processes across many industry sectors including manufacturing and service organisations (Lobo et al., 2018: 1232). Especially it tends to play a pivotal role in the success of the service industry, owing to the intangible nature of services (Famiyeh et al., 2017: 1546). But in most industries, quality has never mattered more (Cronemyr et al., 2017: 498) - knowledge-based economy conditions challenge organisations to become more agile and continuously innovate and improve their processes.

Today, the focus on quality is a sine qua non-condition of the functioning and success of an organization and, at the same time, one of the main tasks for managers (Ali and Musah, 2012: 289). It results in a different approach to competitiveness, relations with customers and suppliers or relations between managers and employees (Troy and Schein, 1995, p. 45).

It's worth to stress that quality management has developed enormously since its origins (Kemenade and Hardjono, 2019: 150), because in quality approach there has been shift in understanding and focus from «hard» aspects such as tools, techniques, practices and systems to «soft» behavioural and cultural elements (Tenji and Foley, 2019: 401). The new, the namely fourth quality paradigm has emerged, purporting that quality shall be a value shared amongst everyone in the organisation: quality is a way of life (Kemenade and Hardjono, 2019: 153). The concept «Quality is Value philosophy» (Gouda et al., 2019: 56) began to be applied. Therefore organisational culture has become the most significant factor in the success or failure of quality initiatives (Tenji nad Foley, 2019: 401). Moreover, numerous studies proved that organisational culture is one of the most important variables in the success or failure of TQM implementation (Patyal and Koilakuntla, 2018: 1407-1408). For example, it seems to strengthen the 
positive relationship between service quality dimensions and customer satisfaction (Famiyeh et al., 2017: 1546).

Taking into account the results of research, according to which strategy must precede culture and culture must be aligned (Kaul, 2019: 116) and considering the necessity of a pro-quality orientation in organisation management, an obvious line of reasoning arises, consistent with the fourth paradigm of quality. Since organisational culture should condition the strategy and modern strategies have to be focused on quality, enterprises should strive to shape an organisational culture that combines these tasks by fitting within the conditions of the knowledge-based economy. Therefore, they are facing the challenge of having an organisational quality culture as the element underlying all activities. Especially as strategic quality orientation directly affects innovation capabilities and therefore should be leveraged form quality culture (Khan and Naeem, 2018: 1568).

Organisational culture has often been regarded as the main factor or inhibitor for organisational strategies, especially those related to quality (Karakasnaki et al., 2019). Moreover, it is recognized by many as a critical factor when applying quality management initiatives. At the same time, these initiatives fail to reach their potential because leaders lack an understanding of the key role of organisational culture in quality. They're ignoring the role of values, behaviours and attitudes in spite of the fact that there is a strong link between performance management and organizational culture that leaders need to understand to help them reach full quality development (Ingelsson et al., 2018: 1751). It is also proved, that the key reasons for failures of quality management processes implementation are partial deployment and lack of understanding of organisational culture (Patyal and Koilakuntla, 2018: 1407). Consequently, quality culture was introduced to provide a comprehensive approach to quality sustainability (Ali and Musah, 2012: 290; Wu, 2014: 800).

Companies that had successfully achieved a quality culture, had generally recorded immense benefits in all-round total quality improvement within their organisations. Commonly, the focus had changed form problem solving to building on their success (Adebanjo and Kehoe, 1999: 640). A company with highly developed culture of quality spends, on average, $\$ 350$ million less annually fixing mistakes than a company with poorly developed one (Srinivasan and Kurey, 2014: 59).

Because of the fact that in some sectors quality culture has not been properly developed (Lo, 2002: 272) and also general agreement that there is a gap to be filled in the development of appropriate culture for quality (Adebanjo and Kehoe, 1998: 275) or complaints that instruments are in place but there is a lack of quality culture - successful quality improvement practices seem to require both the formal side and a quality-conductive organisational culture in terms of attitudes and practices of participants (Markowitsch, 2018: 25), the main purpose of the study is to provide an initial comparative verification of which stage of evolution towards quality culture is represented by companies from different industries in Poland.

The discussion of the empirical research conducted seems to be justified and valuable, especially as the level of desire to understand and improve quality culture is currently higher than the level of its practical implementation, which is unsurprising for a newly emerging topic (Emond and Taylor, 2018: 374).

The paper has a theoretical-empirical ladder. Using research of the literature, a discussion was held focused on capturing the essence, determinants and evolutionary stages of quality culture. Based on exploration of empirical data, a challenge was taken up, aiming at diagnosing the condition of quality culture in companies operating in Poland.

Literature Review. The main feature of the new economy is the treatment of knowledge as the most important resource of a contemporary organization as well as assignment of an attribute of dominance thereto. As a result, companies presently should naturally strive to make efforts aiming at creation of such organizational cultures which would affirm knowledge, namely cultures preferred under the conditions of the new economy and characteristic for organizations based on knowledge. 
Therefore, most often convergent and mutually complementary: lean culture (Pereira Paro and Gerolamo, 2017: 586), learning organization culture (Kaul, 2019: 128) knowledge culture (Glinska-Newes, 2007: 231), information culture (Daneshmandnia, 2019: 20), cooperation culture (Kaminska, 2013: 13), trust culture (Sankowska, 2011: 93), group-development culture (Patyal and Koilakuntla, 2018: 1406) and quality culture (fig. 1) are identified.

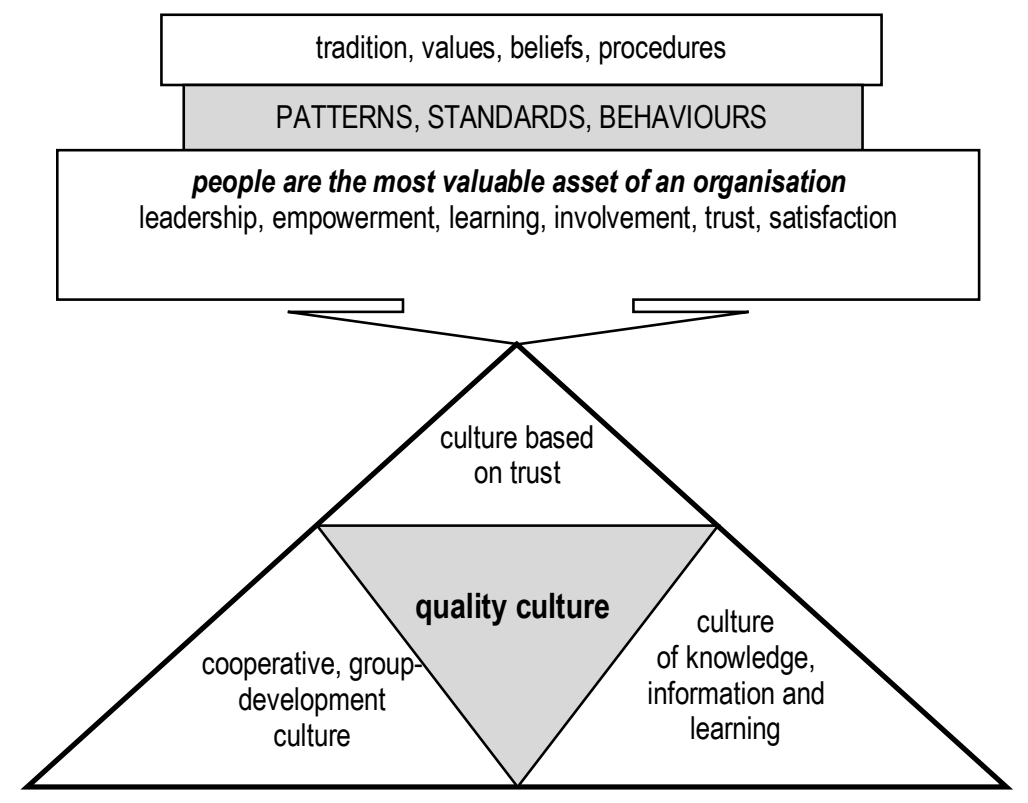

Figure 1. Dependencies between types of organisational cultures in the knowledge economy Source: Prepared by the author.

All these types of organisational culture foster engagement of employees, building trust and sharing knowledge. They allow for freedom of action, promote teamwork, give a sense of community and ownership, enable efficient communication, prefer openness to changes and proactive attitude thus stimulating the circulation of knowledge, and emphasize its dominant character for the success of an organization (Juchnowicz, 2012: 26-28). In these terms, organisational culture of modern enterprise is described as an umbrella term under which multiple cultures may exist (Manning, 2018: 287). But as the basic and the core element of any type of contemporary organisational culture we should identify and treat human behaviour as central to organisations and culture and as the key to understanding and affecting change in human behaviour within organisations (Taylor and Rostron, 2018: 313).

Although according to L. Sulkowski (2013b: 25), it seems quite methodologically risky to combine the notions of organisational culture with quality into the concept of quality culture, many theoretical and practical studies discuss these issues.

The greatest consternation is aroused by the interdependencies between the organisational culture and the quality culture. There are four positions began to be applied (Ehlers, 2009: 350-352; Markowitsch, 2018: 29-30). Some researchers believe that quality culture can be identified as part of the organisational culture - it is sort of a thematic subculture. Others believe that quality culture may share some elements or dimension of organizational culture but may also have some different key values not covered in common organizational culture concepts. It is also possible to encounter an opinion that quality culture is identical 
with organisational culture and just used as another term for it or an extreme view, according to which quality culture is a genuine construct different from organizational culture and quality culture cannot be described on the basis of models of organisational culture.

Due to the existence of numerous approaches, quality culture is a vast topic - it involves the psychological, technical and managerial aspects, as well as the visible and invisible elements, the stable and dynamic perspectives (Taylor and Rostron, 2018: 314). It is an issue also widely discussed by both practitioners and researchers, but it has no clear definition (Cronemyr et al., 2017: 515). Moreover, even among researchers, there is still no agreement as to the methods of interpreting and studying the organisational culture of quality, which is proven by the diversity of definitions of the analysed phenomenon (table 1).

Table 1. Overview of definitions of the organisational culture of quality Berry (1997: 54)

The total of collective or shared learning of the quality-related values as the organization develops its capacity to
survive in its external environment and to manage its own internal affairs
Ali and Musah (2012: 290)
$\begin{gathered}\text { Overall attitude of an institution, which focuses on the concept of quality and applies it to all aspects of its } \\ \text { activities; an institution as a whole has embraced quality in every element of functionality that enhances } \\ \text { continuous improvement; it's a learning culture in which all members of institution are involved in a self-critical } \\ \text { assessment and improving culture in which all of the workforce of institution is fully engaged in all activities } \\ \text { carried out by the institution } \\ \text { Ngyuen Duy Nong Ha and Bui Ngoc Quang (2014: 1) } \\ \text { Refers to an organisational culture that intends to enhance quality permanently and it is characterised by two } \\ \text { distinct elements: on the one hand, a cultural/psychological element of shared values, beliefs, expectations and } \\ \text { commitment towards quality and, on the other hand, a structural/managerial element with defined processes that } \\ \text { enhance quality and aim at coordinating individual efforts } \\ \text { Srinivasan and Kurey (2014: 58) } \\ \text { An environment in which employees not only follow quality guidelines but also consistently see others taking } \\ \text { quality-focused actions, hear others talking about quality, and feel quality all around them } \\ \text { Markowitsch (2018: } 28) \\ \text { Composition of the two quality management elements - technology and commitment culture. Commitment is } \\ \text { described as the cultural aspects of an organisation's quality culture }\end{gathered}$
Source: prepared by the author on the basis of literature indicated in the table.

Source: prepared by the author on the basis of literature indicated in the table.

The notion of quality culture directly refers to the notion of organisational culture and its definition, designating patterns, behaviours, standards, and beliefs related to quality (Bugdol, 2013: 213). Such a culture is thus a collection of values, traditions, procedures, and beliefs approved by members of the organisation, creating the environment fostering shaping of and continuous improvement in quality (Golebiowski, 2014: 33). It contains three basic elements - system wide philosophy (doing the right thing the first time), continuous improvement (striving for that), and customer focus (fulfilling customer needs) (Wu et al., 2011: 266; Wu, 2014: 804). Its symptoms include empowerment, full commitment of employees to quality, as well as qualitative leadership, and its products are - satisfaction of internal and external customers and business performance (Bugdol, 2013: 213-242).

The most often listed activities focused on building quality culture are: focus on customer satisfaction, focus on processes, teamwork, open communication and exchange of knowledge, focus on making decisions based on facts (Adebanjo and Kehoe, 1998: 276-277; Ali and Musah, 2012: 290; Ingelsson et al., 2018: 1755-1756). In shaping quality culture, the greatest significance is thus attributed to interpersonal relationships, treatment of employees and customers with respect, focus on development, acquisition of licenses, and co-participation in organization management. Then, the central place is taken by the critical 
importance of trust in relations at the level of an individual, as well as in relations between the employee and the organization, and between the client and the organization (Ehlers, 2009: 351).

Concluding, as the basic dimensions of organisational quality culture following issues can be accepted (Khan and Naeem, 2018: 1579): measurable and time-based quality goals are included in the development of long-term plans, organisation have common, strict and stables values, beliefs based on trust and openness, quality performance, goals and initiatives are communicated to firm's employees, clients and all stakeholders on regular basis.

Organisational quality culture may be thus defined through a set of indicators attributed to 3 categories verifying its condition - the level of the employee, the superior and the whole organization (Molenda, 2012: 210-219). It can also be measured in accordance with specific categories (people, processes, proactivity, purpose) and dimensions of these categories (Taylor and Rostron, 2018: 318-325).

To sum up, in contemporary economy having the right culture - particularly quality culture - is a key success factor for any business (Emond andTaylor, 2018: 369).

Methodology and research methods. In spite of the facts that culture is highly contextual and requires a research process that facilitates depth and discovery (Taylor and Rostron 2018: 326), and measuring quality culture is not an easy task (Cronemyr et al., 2017: 505), but also owing to the observation that the importance of quality culture is increasingly recognized across a wide range of industries, however the challenges remain in terms of how to quantify and change it (Kane et al., 2018: 391 ), the goal of conducting preliminary research on the condition of the quality culture in enterprises operating in Poland was set.

Having regard to the report that there is a need for a tool that measures not only quality values but also behaviours that support or obstruct a quality culture (Cronemyr et al., 2017: 498), a decision was made to undertake initial research, above all, in the field of values and attitudes aimed at building a quality culture in the perspective of the employee, manager and organisation, with a distinction between production, service and mixed enterprises. According to this breakdown, efforts were also made to capture the quality culture features occurring in the enterprises reviewed.

At the beginning of the research work, conducted with the purpose of initial analysis and diagnosis of orientation towards quality culture in Polish enterprises, the following hypotheses were formulated:

- standards of behaviour are observed in enterprises that contribute to the emergence of an organisational quality culture in the entities studied,

- $\quad$ in enterprises, in view of the type of business, there are various manifestations of quality culture in the areas of the employee, manager and organisation,

- the organisational cultures of service enterprises have more clearly observable features of quality culture determining their competitive advantage in comparison with companies carrying out other forms of activity,

- $\quad$ organisational cultures, from the point of view of the business profile of enterprises, are heading in varying degrees towards the 3rd stage of evolution of quality culture, that is to say, the state of continuous quality creation.

Theoretical assumptions formulated in this way led to the emergence of specific research questions:

- what are the distinguishing factors of an organisational culture focused on quality in the organisations reviewed and do they differ depending on the type of business?

- what indicators of quality culture at the level of the employee, manager and the whole organisation are observed in the enterprises studied and are they varied taking into account the profile of the analysed companies?

- $\quad$ what are external and internal stakeholders of these enterprises' levels of satisfaction with their functioning, and is it different for various types of activity of the studied organisations? 
In order to verify the hypotheses put forward and to implement the research challenges formulated in the form of questions, in practice, a survey questionnaire was carried out in 2018 and the 1st half of 2019. The research tool included 20 closed-ended questions - most of them multiple choice (that is why the respondents' answers do not add up to $100 \%$ ).

It was decided to research, in the context of quality culture, all enterprises: those operating in production, those operating in services and also mixed enterprises. This is due to the general conclusions from the literature analysis suggesting the need for pro-quality orientation and, thus, the supreme importance of the quality culture in every sphere of the organisation's functioning, regardless of the company's profile.

Eventually, 238 complete questionnaires were obtained, and each respondent was from a different organisation - the study was therefore only a general, pilot one, although cross-sectional. The respondents were usually employees of moderate experience, with average professional experience of 5.5 years, and with average employment of 3.5 years in the organisation characterised in the survey, which assures that they had enough knowledge about the organisation described by them as its employees.

When it comes to the activity of the analysed organisations, the profile was diverse. $28 \%$ of the surveyed enterprises are involved in production, $22 \%$ in trade, and $40 \%$ in services. $10 \%$ of the enterprises reviewed represented a mixed profile. Most of them were experienced entities, operating under various market conditions - with an average company age of 15 years.

Thus, the structure of the research sample reflected the general tendencies resulting from the prevailing conditions of the knowledge-based economy, characterised by the services sector taking a dominant role over manufacturing sectors. Therefore, it was possible to speculate that the operation of the majority of organisations reviewed was in line with the principles of the new economy, in which organisational cultures should be knowledge-oriented and their development should be towards a culture of quality, shaped in a conscious and controlled manner, especially in the case of large entities, which were the prevailing group in the sample.

The companies described in the study were also diverse when it comes to size $-21 \%$ of them were microenterprises, $23 \%$ were small, $24 \%$ were medium, and $32 \%$ were large organisations. In the respondents' opinion, most of them had a satisfactory financial position $(34 \%$ of respondents stated that the companies they described were in a very good financial position, $54 \%$ stated good, and $12 \%$ stated average). The stable financial situation of the companies reviewed suggested that the surveyed enterprises should represent attitudes of openness, show a greater tendency to take risks, search for new areas of development and be quality-oriented.

Results. When seeking answers to the research questions asked, reference was made to answers given by the respondents. First, an attempt was made to analyse and diagnose the stage of evolution of the enterprises reviewed towards a culture of quality. The answers obtained generally indicate that the entities described are moving from the phase of lack of emphasis on quality, to the stage of error detection and prevention of quality errors, and the stage of continuous quality creation. This is evidenced by the frequency of actions and attitudes indicated by the respondents that are an emanation of quality culture, at the level of the employee, manager and organisation. Nonetheless, the respondents simultaneously identify the areas clearly slowing down the achievement of specific development phases towards the stage of full focus on quality, which is suggested by the emergence of quality culture itself and not by its existence in a specific formula.

Significantly, the place of particular types of enterprises, in light of their business profile, is varied. It can be observed that manufacturing enterprises are at the earliest stage of pursuing a full quality culture and are followed by mixed, then commercial enterprises, while service enterprises are closest to the stage of maturity in shaping quality culture. 
Arguments confirming this thesis are provided by respondents' statements relating to the actions and attitudes most often visible in their organisations that prevent the transformation of organisational culture towards one promoting quality (figure 1). These are mainly: treating knowledge as a source of power, allocation of full responsibility for the functioning of organisation only to managers, and keeping financial decisions in total secrecy.

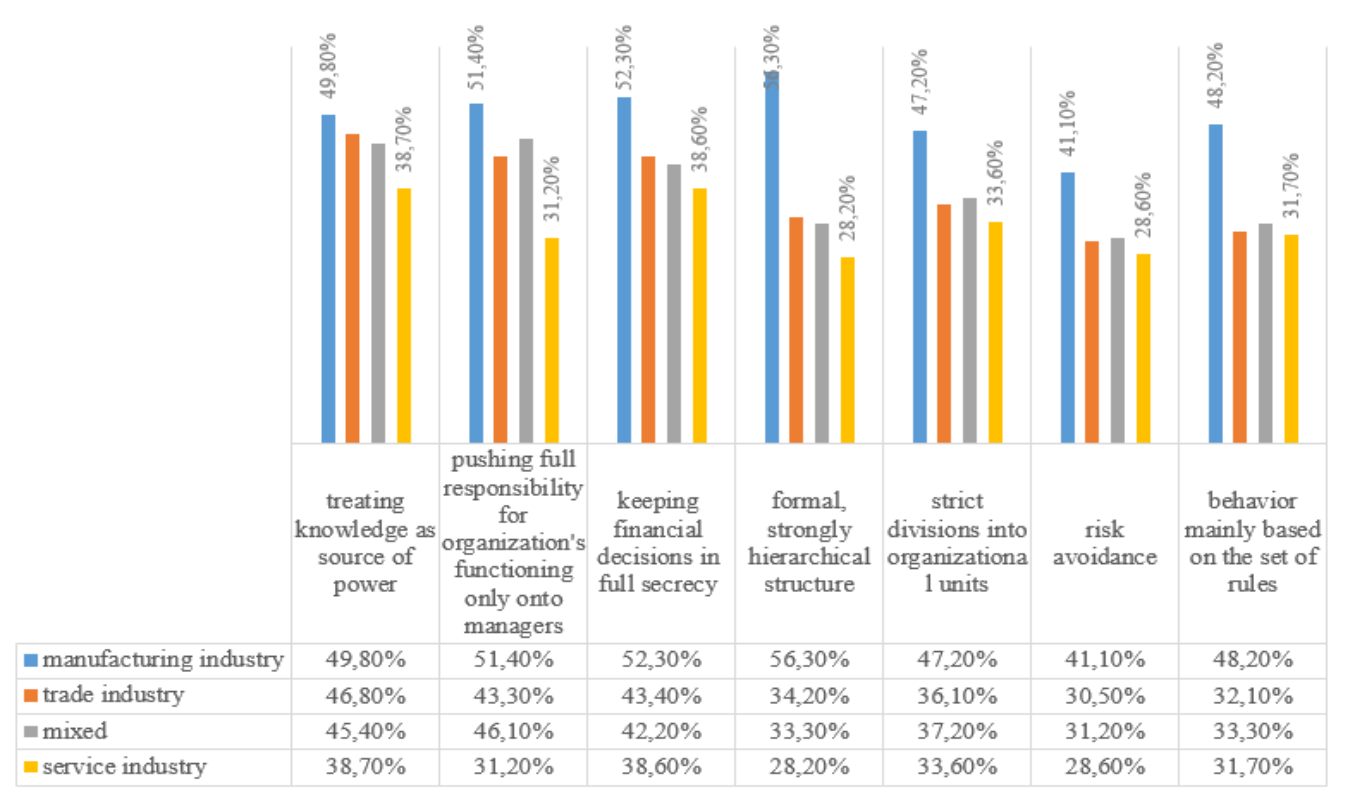

Figure 1. Behaviours and attitudes that hinder evolution of organizational culture towards

Source: own elaboration. quality culture

Reinforced with a formal, strongly hierarchical structure, including strict separations into organisational units, risk avoidance and conduct based mainly on clichéd rules, they essentially limit the tendency to share knowledge, innovation, search for new solutions or show initiative. Lack of transparency and rigid rules are not conducive to trust or openness and thus limit creativity, commitment and determination to seek perfection, which is manifested in the affirmation of quality.

Determination to shape a pro-quality organisational culture in the studied organisations is reflected in the most common standards of behaviour identified by the respondents, which are obligatory in the organisations described by them: knowledge sharing as a value, being «customer-oriented», informal communication methods, continuous training and education of employees, evenly shared responsibility, a culture of shared responsibility and promotion of entrepreneurship. The trend line is similar also in this case. These principles are most noticeable within service enterprises, then in trade and mixed enterprises, and finally in manufacturing enterprises (figure 2).

Focusing on the 3 identified levels of quality culture indicators (employee, manager, organisation), they were indicated by the respondents to a moderate degree, which further confirms the supposition that the organisations reviewed are just evolving towards a crystallised organisational quality culture, and this development has different paces in view of the business profile (table 2). 


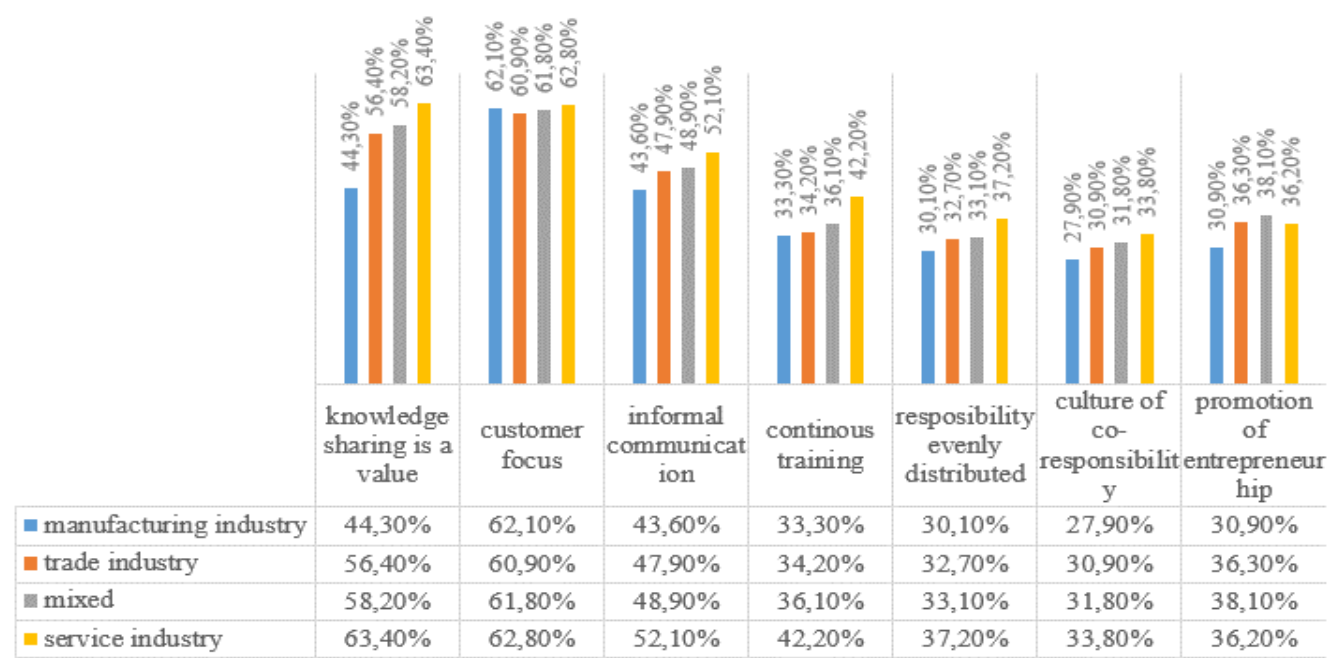

Source: own elaboration

Figure 2. Prevalent principles in organizations

Table 2. The indicated determinants of quality culture in the perspective of the employee, the superior and the organization

\begin{tabular}{|l|c|c|c|c|}
\hline \multicolumn{1}{|c|}{ the employee } & $\mathbf{S}$ & $\mathbf{M}$ & $\mathbf{T}$ & $\mathbf{P}$ \\
\hline is fully involved in performance of his/her duties & $49,1 \%$ & $49,4 \%$ & $48,8 \%$ & $46,3 \%$ \\
\hline has a precisely determined scope of responsibilities & $41,2 \%$ & $40,4 \%$ & $43,4 \%$ & $44,4 \%$ \\
\hline is supported by managerial staff in the performance of his/her duties & $42,4 \%$ & $40,6 \%$ & $40,9 \%$ & $39,9 \%$ \\
\hline has the opportunity to improve his/her competences & $51,7 \%$ & $55,7 \%$ & $44,8 \%$ & $43,2 \%$ \\
\hline complies with the binding procedures, instructions & $39,7 \%$ & $39,5 \%$ & $39,6 \%$ & $41,2 \%$ \\
\hline commits to improvement of his/her job & $29,6 \%$ & $28,8 \%$ & $30,5 \%$ & $31,2 \%$ \\
\hline is thoroughly familiar with his/her duties & $61,3 \%$ & $60,3 \%$ & $61,1 \%$ & $61,0 \%$ \\
\hline has sufficient competencies to perform the assigned duties & $38,8 \%$ & $38,6 \%$ & $37,9 \%$ & $36,6 \%$ \\
\hline takes care of his/her workstation & $53,2 \%$ & $52,3 \%$ & $50,1 \%$ & $54,3 \%$ \\
\hline is well-motivated to perform his/her duties & $38,9 \%$ & $33,4 \%$ & $39,2 \%$ & $36,2 \%$ \\
\hline & $\mathbf{S}$ & $\mathbf{M}$ & $\mathbf{T}$ & $\mathbf{P}$ \\
\hline supports employees in performance of their tasks & $40,6 \%$ & $37,2 \%$ & $39,8 \%$ & $39,7 \%$ \\
\hline is focused on fulfilment of customer's requirements & $61,4 \%$ & $59.9 \%$ & $59,7 \%$ & $60,9 \%$ \\
\hline enables employees to participate in trainings & $42,9 \%$ & $39,6 \%$ & $39,3 \%$ & $38,7 \%$ \\
\hline encourages employees to increase their qualifications & $33,6 \%$ & $32,8 \%$ & $34,6 \%$ & $30,9 \%$ \\
\hline \multicolumn{1}{|c|}{ the organization } & $\mathbf{S}$ & $\mathbf{M}$ & $\mathbf{T}$ & $\mathbf{P}$ \\
\hline priority treatment of meeting customer's requirements & $47,3 \%$ & $46,9 \%$ & $47,1 \%$ & $47,2 \%$ \\
\hline $\begin{array}{l}\text { mandatory fulfilment of legal and technical requirements by the } \\
\text { product/service }\end{array}$ & $38,2 \%$ & $37,9 \%$ & $38,3 \%$ & $44,3 \%$ \\
\hline cooperation with the best suppliers & $37,4 \%$ & $36,9 \%$ & $38,6 \%$ & $36,4 \%$ \\
\hline continuous investment in the most advanced machines and devices & $23,1 \%$ & $22,9 \%$ & $22,8 \%$ & $25,8 \%$ \\
\hline very good cooperation between employees & $52,9 \%$ & $50,4 \%$ & $53,2 \%$ & $47,6 \%$ \\
\hline elimination of products/services inconsistent with the requirements from the & $18,8 \%$ & $17,4 \%$ & $16,9 \%$ & $25,3 \%$ \\
\hline order execution process & & & & \\
\hline use of techniques and methods of quality improvement & $38,7 \%$ & $36,4 \%$ & $37,2 \%$ & $42,6 \%$ \\
\hline
\end{tabular}

Source: own elaboration. 
At the employee level, the pursuit of quality culture is manifested to a large extent through good knowledge of duties, the ability to improve skills and full commitment to the performance of one's own duties. In the case of managers, their dedication to the development of the quality culture manifests itself in the focus on meeting customer expectations and supporting employees in fulfilling their duties, and enabling their participation in training. In turn, leaders should pay more attention to encouraging their employees to upgrade their qualifications, while increasing the strength of their real influence on colleagues.

While referring to the level of building a quality culture in the organisation, the respondents most often pointed to very good co-operation between employees, encouraging the emergence of voluntary cooperative attitudes and civic behaviour, prioritisation of meeting the expectations of customers, and the use of techniques and methods for improving quality.

Among the observed factors stimulating the emergence of a quality culture, the respondents mentioned: great freedom of action, teamwork and communication efficiency. Again, they are most clearly visible within service enterprises. Other elements catalysing the emergence of a culture of quality are less evident - openness to changes and proactive attitudes. Therefore, these should be developed and efforts should be focused on them (figure 3).

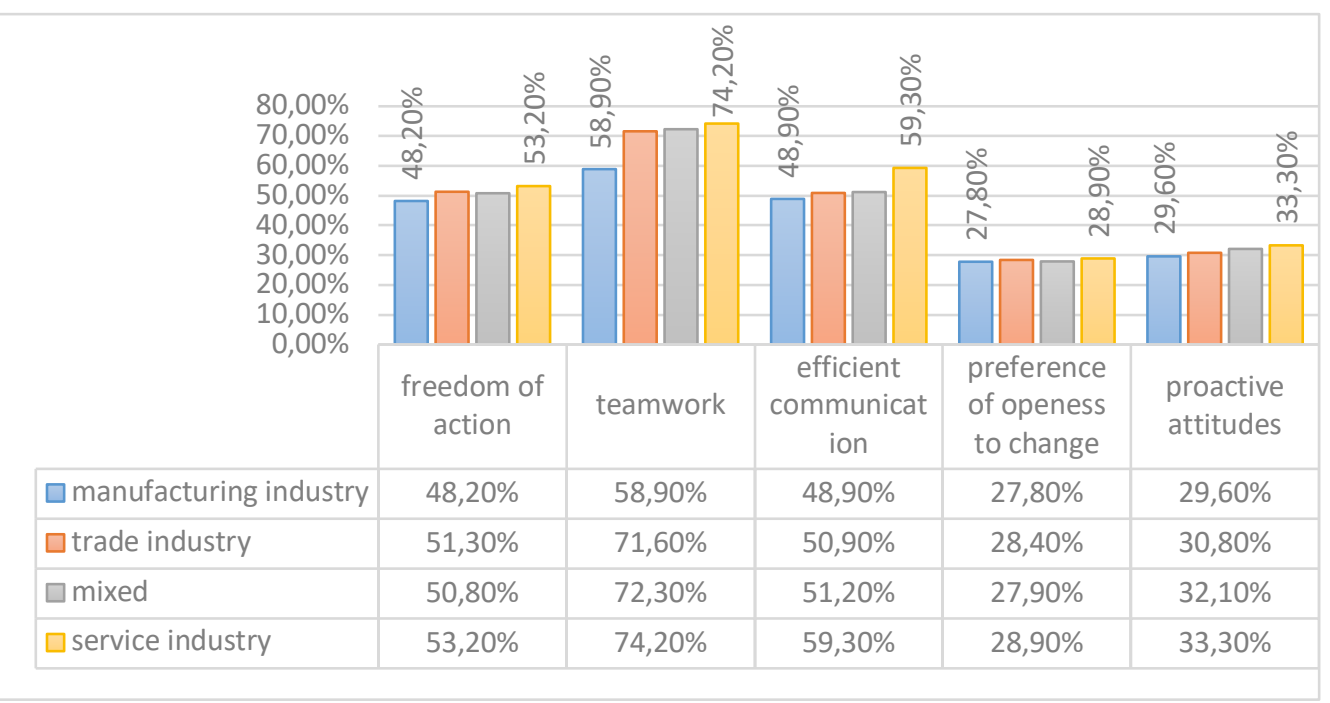

Figure 3. Factors stimulating the emergence of quality culture

Source: own elaboration.

According to the respondents, the tools most commonly used that stimulate the emergence of a permanent state of organisational quality culture are, in turn: team work, fulfilment of obligations to employees, raising awareness of the company's goals and clear principles of conduct, TQM, and management acting as role models of openness and honesty among other behaviours.

Professionals are relatively rarely promoted and trained. Therefore, striving for excellence remains more in the hands of the employees themselves; professionalism is not the focal point and perhaps that is why the respondents emphasise that choosing the right staff is a rare phenomenon (figure 4). 


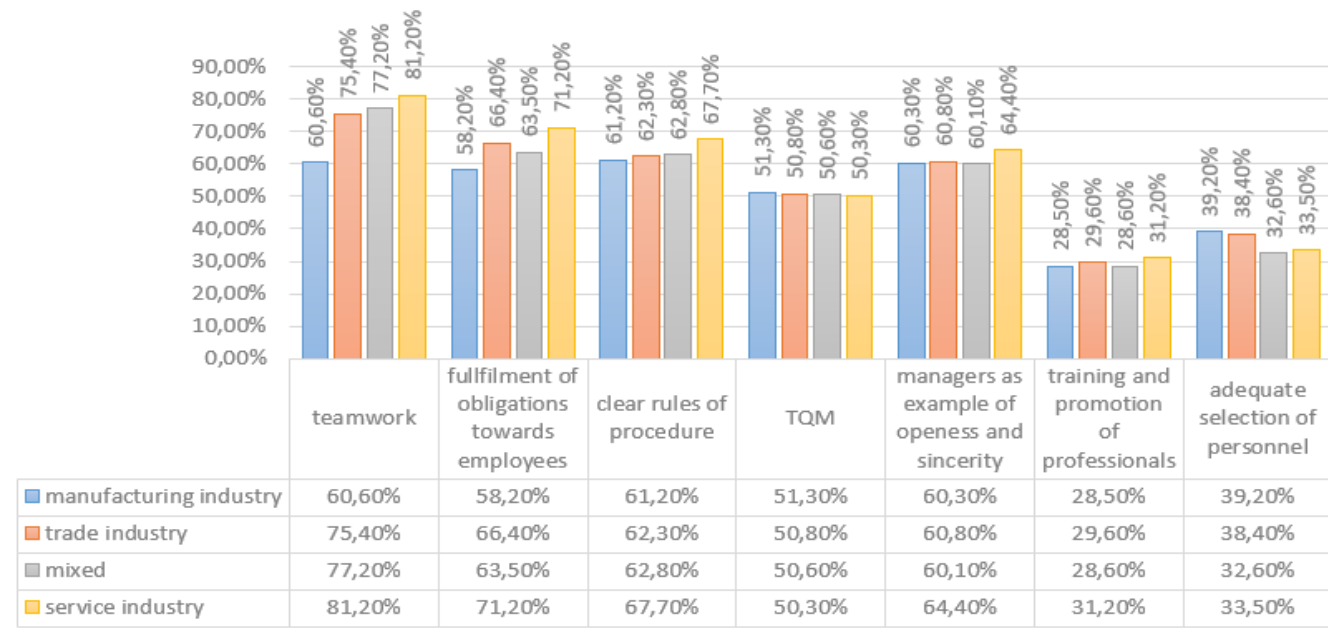

Figure 4. Tools stimulating the emergence of permanent quality culture

Source: own elaboration.

Finally, in the opinion of respondents, regardless of the business profile, external customers are more satisfied with the surveyed organisation (average level of satisfaction indicated equal to $92.4 \%$ ) than the reviewed enterprises with customer relations (average level of satisfaction equal to $84.5 \%$ of responses).

To sum up, the surveyed enterprises operating in Poland are undergoing transformations in their organisational cultures towards a quality culture, because the respondents, their employees, indicate in the companies described the features of quality culture that determine their success (table 3 ). These are: high standards of activity, the importance of people in achieving the organisation's success, and informal pro-quality behavioural rules.

Nonetheless, none of the distinguished attributes exceed $50 \%$ of responses, which may suggest that they are following the road to a permanent stage of quality affirmation in each of the mentioned dimensions. Therefore, efforts should be taken to develop the following mechanisms: widely shared philosophy of comprehensive quality management, popularization and consolidation of quality culture, as well as distinguishing successful people and publicizing their awards in the field of quality.

Table 3. Characteristics of quality culture of enterprises operating in Poland

\begin{tabular}{|l|c|c|c|c|}
\hline Industry (service, trade, mixed, manufacturing - P) & $\mathbf{S}$ & $\mathbf{T}$ & $\mathbf{M}$ & $\mathbf{P}$ \\
\hline widely shared philosophy of comprehensive quality management & $15,3 \%$ & $13,4 \%$ & $15,1 \%$ & $14,8 \%$ \\
\hline importance of people in achieving success of the organisation & $46,0 \%$ & $43,2 \%$ & $42,5 \%$ & $40,1 \%$ \\
\hline celebrations marking events in the organisation's life & $35,3 \%$ & $33,3 \%$ & $34,1 \%$ & $35,1 \%$ \\
\hline $\begin{array}{l}\text { awarding successful people and publicising their awards in the field } \\
\text { of quality }\end{array}$ & $29,4 \%$ & $28,4 \%$ & $27,6 \%$ & $27,4 \%$ \\
\hline popularising and consolidating the quality culture & $27,3 \%$ & $26,3 \%$ & $25,4 \%$ & $27,7 \%$ \\
\hline informal rules of conduct & $39,7 \%$ & $33,5 \%$ & $35,4 \%$ & $33,9 \%$ \\
\hline strong values & $37,3 \%$ & $36,6 \%$ & $36,4 \%$ & $36,9 \%$ \\
\hline high standards of operation & $47,3 \%$ & $46,4 \%$ & $45,9 \%$ & $46,8 \%$ \\
\hline corporate character & $31,0 \%$ & $28,6 \%$ & $25,4 \%$ & $22,6 \%$ \\
\hline
\end{tabular}

Source: own elaboration. 
The key thus lays in changing the way of thinking at the level of the employee, the superior and the entire organization, namely shifting the focus to soft aspects of management and strong values constituting their basis.

Conclusions. Organizational culture is a complex phenomenon - changing it takes time and effort, especially from organizations' leaders (Ingelsson et al., 2018: 1760). Managers must decide and be convinced that a culture of quality is worth pursuing. In an environment where customers' tolerance for quality problems is declining, a workforce that embraces quality as a core value is a significant competitive advantage (Srinivasan and Kurey, 2014: 65).

Achieving the level of permanent organizational quality culture is an evolving process. At the early stage of quality management implementation, when a quality culture is not firmly established, it is organisational culture that has a strong influence on employee behaviour. Thus, organisational culture, at first, seems a more stable and appropriate predictor than quality culture (Tenji and Foley, 2019: 400).

From this line of reasoning, the following continuum emerges: TQM implementation $\rightarrow$ Organizational culture $\rightarrow$ Quality culture $\rightarrow$ Organizational Quality Culture. However, we should note that the values within the quality culture can be found in the second level of the organisational culture - espoused values (Cronemyr et al., 2017: 500). They are associated with the following values: sociability, solidarity, integration, differentiation, fragmentation, consensus, pervasiveness, psychological intensity, adaptability, involvement, consistency, and mission (Tenji and Foley, 2019: 408).

In the evolution towards organisational quality culture, core-culture keeps the culture of the organisation vibrant and resilient (Kaul, 2019: 120) and this core-culture should be quality culture. Therefore, it's worth mentioning that community culture seems to be the strongest predictor of reliability, assurance, responsiveness and empathy, while innovative culture was found to have the strongest influence on the tangibles dimension (Karakasnaki et al., 2019). Also, the group culture and development culture are the most supportive cultures forming both infrastructure and core quality practices. Thus, managers need to be competent in managing teams, interpersonal relationships and look for innovation and new resources. They should favour teamwork and help individuals improve their performance, expand their competencies and get rewarded for their contribution to better quality (Patyal and Koilakuntla, 2019: 1419).

On their planned path towards organisational quality culture, managers should ask themselves specific questions and find positive answers to them:

- employees feel that they are individually and collectively responsible for quality,

- the role of the specialised quality department is seen as facilitating quality improvement and not being solely responsible for quality improvement,

- the quality department is responsible for initiating, planning or implementing quality initiatives within various departments and also facilitating or conducting quality enhancement efforts under the leadership of top management,

- the organisation has formal quality management practices in all functional areas,

- the organisation acknowledges the importance of functional excellence but focuses on performance achievement (Lobo et al., 2018: 1247).

To sum up, first of all, managers must have a deep internal conviction that affirmation of quality fosters the success of the contemporary organization. This conviction should be expressed in their actions and attitudes focused on both employees and customers. High quality of human capital management, supported by focus on quality, must be reflected in a culture promoting knowledge, trust, learning, and engagement - quality culture.

The analysed results should be treated only demonstratively, as they have clear restrictions due to the size of the research sample and research method - self-designed questionnaire. The study should be considered only as a pilot study, confirming the pursuit of transformation of organizational cultures of 
companies operating in Poland into quality culture. It can warrant further scientific exploration of the tackled problems in a cross-section of various sectors and strive to create a comprehensive model of building quality culture, taking account of the perspective of the employee, the superior, the organization, the customer, and the whole sector embedded in the context of cultural diversity or the network society.

Acknowledgements/Funding: Publication was financed from the funds granted to the Faculty of Management at Cracow University of Economics, within the framework of the subvention for the maintenance of research potential; by Minister of Science and Higher Education titled "Regional Initiative of Excellence" in 2019-2022, project number 018/RID/2018/19, the amount of funding PLN 10788423,16

\section{References}

Adebajo, D. Kehoe, D. (1998), An evaluation of quality culture problems in UK companies, International Journal of Quality, 3(3): 275-286.

Al Saifi, S.A. (2015), Positioning organisational culture in knowledge management research, Journal of Knowledge Management, 19 (2): 164-189.

Ali, H.M., Musah, M.B. (2012), Investigation of Malaysian higher education quality culture and work performance, Quality Assurance in Education, 20(3): 289-309.

Ambekar, S., Prakash, A., Patyal, V.S. (2019), Role of culture in low carbon supply chain capabilities, Journal of Manufacturing Technology Management, 30(1):146-179.

Berry, G. (1997), Leadership and the development of quality culture in schools, International Journal of Educational Management, 11(2): 52-64.

Bugdol, M. (2013), Kultura jakosci jako wyraz filozofii zarzadzania, in: T. Oleksyn (Ed.), Filozofia a zarzadzanie (213-242), Warszawa: Oficyna Wolters Kluwer Polska SA.

Corfield, A., Paton, R. (2016), Investigating knowledge management: can KM really change organisational culture?, Journal of Knowledge Management, 20(1): 88-106.

Cronemyr, P., Backstrom, A., Ronnback, A. (2017), Quality culture deployment - using behaviours to explain, diagnose and improve a quality culture, International Journal of Quality and Service Sciences, 9(3/4): 498-518.

Daneshmandnia, A. (2019), The influence of organizational culture on information governance effectiveness, Records Management Journal, 29(1/2): 18-41.

Ehlers, U.D. (2009), Understanding quality culture, Quality Assurance in Education, 17(4): 343-364.

Emond, B., Taylor, J.Z. (2018), The importance of measuring food safety and quality culture: results from a global training survey, Worldwide Hospitality and Tourism Themes, 10(3): 369-375.

Endara, Y.M., Ali, A.B., Ab Yajid, M.S. (2019), The influence of culture on service quality leading to customer satisfaction and moderation role of type of bank, Journal of Islamic Accounting and Business Research, 10 (1): 134-154.

Famiyeh, S., Asante-Darko, D., Kwarteng, A. (2018), Service quality, customer satisfaction, and loyalty in the banking sector: The moderating role of organizational culture, International Journal of Quality \& Reliability Management, 35(8): 1546-1567.

Glinska-Newes, A. (2007), Kulturowe uwarunkowania zarzadzania wiedza w przedsiebiorstwie, Torun: Wydawnictwo Dom Organizatora.

Golebiowski, M. (2014), Elementy kultury jakosci w organizacji, Studia i Prace Wydzialu Nauk Ekonomicznych i Zarzadzania, 38(1): 33-42.

Gouda, S. K., Awasthy, P., Krishnan T. S., Sreedevi R., (2019), What does «green quality» really mean?, The TQM Journal, 31(1): 52-69.

Ingelsson, P., Backstrom, I., Snyder K. (2018), Strengthening quality culture in private sector and health care. What can we learn from applying soft measures?, Leadership in Health Services, 31(3): 276-292.

Juchnowicz, M. (2012), Zaangażowanie pracowników. Sposoby oceny i motywowania, Warszawa: Polskie Wydawnictwo Ekonomiczne.

Kaminska B., (2012), Rola kultury organizacyjnej w funkcjonowaniu wspólczesnych przedsiebiorstw, Przeglad Organizacji, 2: 11-15.

Kane, K., Taylor, J.Z., Teare, R. (2018), Reflections on the theme issue outcomes: Can the culture of safety and quality in organizations be measured and changed?, Worldwide Hospitality and Tourism Themes, 10(3): 391-396.

Karakasnaki, M., Psomas, E., Bouranta, N. (2019), The interrelationships among organizational culture and service quality under different levels of competitive intensity: An application in the shipping industry, International Journal of Quality and Service Sciences, https://doi.org/10.1108/IJQSS-10-2017-0096 (accessed 24 May 2019). 
Kaul, A. (2019), Culture vs strategy: which to precede, which to align?, Journal of Strategy and Management, 12(1): 116-136.

Kemenade, E., Hardjono, T.W. (2019), Twenty-first century Total Quality Management: the Emergence Paradigm, The TQM Journal, 31(2): 150-166.

Khan, B.A., Naeem, H. (2018), The impact of strategic quality orientation on innovation capabilities and sustainable business growth: Empirical evidence from the service sector of Pakistan, International Journal of Quality \& Reliability Management, 35(8): 1568-1598.

Laforet, S. (2016), Effects of organisational culture on organisational innovation performance in family firms, Journal of Small Business and Enterprise Development, 23(2): 379-407.

Latusek, D. (2008), Rola kultury organizacyjnej w zarzadzaniu wiedza, in: D. Jemielniak, A.K. Koźminski (Ed.), Zarzadzanie wiedza. Podrecznik akademicki (161-191), Warszawa: Wydawnictwa Akademickie i Profesjonalne.

Lo, T.Y. (2002), Quality culture: a product of motivation within organization, Managerial Auditing Journal, 17(5): 272-276.

Lobo, R.S., Samaranayake, P., Laosirihongthong, T. (2018), Quality management capabilities of manufacturing industries in the Western Sydney region: Comparative analysis for quality improvement, International Journal of Quality \& Reliability Management, 35(6): 1232-1252

Manning, L. (2018), The value of food safety culture to the hospitality industry, Worldwide Hospitality and Tourism Themes, 10(3): 284-296.

Markowitsch, J. (2018), Is there such a thing as school quality culture? In search of conceptual clarity and empirical evidence, Quality Assurance in Education, 26(1): 25-43.

Molenda, M. (2012), Znaczenie wartosci organizacyjnych w rozwoju kultury jakosci, Zeszyty Naukowe Politechniki Slaskiej. Seria: Organizacja i Zarzadzanie, 63a(1891): 210-219.

Nong Ha, N.D., Ngoc Quang, B. (2014), Factors Influencing the Process of Developing Quality Culture at the University of Social Sciences and Humanities, Vietnam National University-Ho Chi Minh City, Asian Journal of Humanities and Social Sciences, 2(4): $1-9$.

Patyal, V.S., Koilakuntla, M. (2018), Impact of organizational culture on quality management practices: an empirical investigation, Benchmarking: An International Journal, 25(5): 1406-1428.

Pereira Paro, P.E., Gerolamo, M.C. (2017), Organizational culture for lean programs, Journal of Organizational Change Management, 30(4): 584-598.

Pietersen, Ch. (2017), Organizational culture: a foundational perspective, African Journal of Economics and Management Studies, 8(3): 262-273. Difin.

Sankowska, A. (2011), Wplyw zaufania na zarzadzanie przedsiebiorstwem. Perspektywa wewnatrzorganizacyjna, Warszawa:

Srinivasan, A., Kurey, B. (2014), Creating a Culture of Quality, Harvard Business Review, April: 1-8.

Sulkowski, L. (2013a), Funkcjonalistyczna wizja kultury organizacyjnej w zarzadzaniu - dominujacy paradygmat i jego krytyka, Problemy Zarzadzania, 11(4): 20-32.

Sulkowski, L. (2013b), Kultura jakosci w zarzadzaniu, czyli pomiedzy tożsamoscia a kultura organizacyjna, Przedsiebiorczosć i Zarzadzanie, XIV (8): 25-37.

Taylor, J.Z., Rostron, K.I. (2018), The development of a safety and quality culture assessment tool from a longitudinal, mixedmethod research journey, Worldwide Hospitality and Tourism Themes, 10(3): 313-329.

Tenji, T., Foley, A. (2019), Testing the readiness of an organisational culture profile to a TQM implementation, The TQM Journal, 31(3): 400-416.

Tong, C. (2014), The Impact of Knowledge Sharing on the Relationship between Organizational culture and Job Satisfaction: The Perception of Information Communication and Technology (ICT) Practitioners in Hong Kong, International Journal of Human Resources Studies, 5(1): 19-28.

Troy, K., Schein, L. (1995), The quality culture: manufacturing versus services, Managing Service Quality, 5(3): 45-47.

Wu, S.J, Zhang, D., Schroeder, R.G. (2011), Customization of quality practices: the impact of quality culture, International Journal of Quality \& Reliability Management, 28(3): 263-279.

Wu, S.J. (2014), The impact of quality culture on quality management practices and performance in Chinese manufacturing firms, International Journal of Quality \& Reliability Management, 32(8): 799-814.

Wyrostek, M. (2012), Wplyw kultury organizacyjnej na jakosć pracy w przedsiebiorstwie, Rynek - Spoleczenstwo - Kultura, 2: 43-49.

Анна П'єтрушка-Ортил, Ph.D., Краківський економічний університет (Польща).

Вплив організаційної культури на стратегію інноваційного розвитку компанії

У статті визначено, що організаційна культура має прямий вплив на стратегію інноваційного розвитку компанії та є визначальним фактором їі конкурентоспроможності. Автором наголошено, що сучасні компанії повинні формувати організаційну культуру грунтуючись на новітніх знаннях. При цьому внутрішньо корпоративна культура повинна сприяти 
залученню працівників у виробничий процес, обмін знаннями між ними та формувати довіру до компанії. Визначено, що традиційні види організаційної культури $є$ конвергентними i взаємодоповнюючими та можуть бути представлені як: ресурсозберігаюча, самонавчальна, інформаційна та розвитку потенціалу. При цьому виокремлено додатковий тип організаційної культури компанії - якісний. Даний тип $є$ оптимальний для функціонування компанії у інноваційній економіці. Автором наголошено, що зосередження на якості наразі є необхідною умовою виживання та розвитку сучасних компаній. Метою статті $\epsilon$ опис компонентів якісної організаційної культури польських підприємств різних галузей. Автором систематизовано підходи до визначення сутності якісної організаційної культури, їі елементів та детермінант. Для дослідження використано метод теоретично-емпіричної драбини та здійснено в наступній логічній послідовності: ТQМ впровадження $\rightarrow$ Організаційна культура $\rightarrow$ Якісна культура $\rightarrow$ Якісна організаційна культура. Методологію даного дослідження засновано на соціологічному опитуванні респондентів - підприємства, які функціонують у сфері виробництва, надання послуг та змішаних підприємств. Анкета містила 20 питань закритого типу, більшість з яких має декілька варіантів відповіді. Емпіричні результати дослідження дали підстави зробити висновок про тенденціі формування якісноі організаційної культури на підприємствах Польщі. Визначено, що проаналізовані підприємства рухаються до фази створення постійної якісної організаційної культури. Результати дослідження мають практичне значення і можуть бути використані менеджерам під час побудови ефективної якісної організаційної культури компанії.

Ключові слова: емпіричне дослідження, підприємство, організаційна культура, якість, культура якості, управління якістю.

Manuscript received: 15.07.2019

(C) The author(s) 2019. This article is published with open access at Sumy State University. 